\title{
The site of the bite: Leishmania interaction with macrophages, neutrophils and the extracellular matrix in the dermis
}

\author{
Juliana Perrone de Menezes ${ }^{1}$, Elvira M. Saraiva ${ }^{2}$ and Bruno da Rocha-Azevedo $3,4^{*}$
}

\begin{abstract}
Leishmania spp., the causative agents of leishmaniasis, are intracellular parasites, transmitted to humans via the bite of their sand fly vectors. Once inoculated, the promastigotes are exposed to the dermis, which is composed of extracellular matrix (ECM), growth factors and its resident cells. Promastigote forms are phagocytosed by macrophages recruited to the site of the sand fly bite, either directly or after interaction with neutrophils. Since Leishmania is an intracellular parasite, its interaction with the host ECM has been neglected as well as the immediate steps after the sand fly bite. However, promastigotes must overcome the obstacles presented by the dermis ECM in order to establish the infection. Thus, the study of the interaction between Leishmania promastigotes and ECM components as well as the earliest stages of infection are important steps to understand the establishment of the disease, and could contribute in the future to new drug developments towards leishmaniasis.
\end{abstract}

Keywords: Leishmania, Extracellular matrix, Macrophages, Neutrophils

\section{Background}

Leishmaniasis is one of the neglected tropical diseases, with 350 million people in 98 countries worldwide at risk of developing one of the many forms of the disease. This disease is caused by different species of the genus Leishmania - heteroxenous flagellated protozoa that mainly infect macrophages of mammalian tissues. Parasite entry into the dermis of the mammalian host occurs by innoculation during the bite of the sand fly vector during a blood meal [1]. Promastigotes are inoculated in a pool of blood where they interact with leukocytes [2, 3]. Thus, most host-Leishmania interaction studies have focused on the interaction between Leishmania promastigotes and their cellular targets (dermal dendritic cells, neutrophils, and macrophages) [4]. However, at the earliest step of infection after the sand fly bite - promastigotes could be deposited into the extracellular matrix

\footnotetext{
* Correspondence: bruno.darocha-azevedo@utsouthwestern.edu

${ }^{3}$ Programa de Terapia Celular e Bioengenharia, Instituto de Biofísica Carlos Chagas Filho, Universidade Federal do Rio de Janeiro (UFRJ), Rio de Janeiro, Brazil

${ }^{4}$ Present Address: Department of Biophysics, The University of Texas Southwestern Medical Center, 5323 Harry Hines Boulevard, Dallas, TX 75390 USA

Full list of author information is available at the end of the article
}

(ECM) of the dermis and the blood. In this event, promastigotes interact with extracellular matrix and basement membrane proteins [5], before infecting their cellular targets [3]. In this review, we focus on some of the advances in the cell biology of the early stages of the interaction between Leishmania, the dermis microenvironment, composed of its ECM and immune cells such as neutrophils and macrophages.

\section{Interaction between Leishmania and host extracellular matrix}

The ECM is a complex, tissue specific network of biomolecules that gives shape and physical attributes to tissues and also acts as an environmental cue to the cells surrounding its structure [6,7]. The composition and the shape of the ECM leads to distinct cell behavior, such as survival, differentiation, and proliferation as well as cell migration and tissue invasion [8,9]. Collagen $\mathrm{I}$ is the major ECM component of the skin, and fibroblasts are the cells responsible for its synthesis and organization [10]. The other important component of the skin ECM is the basement membrane, composed of laminin and collagen IV, which separates the dermis from the epithelial layer [11]. During injury, skin structure is damaged, 
leading to the activation of wound healing, which is a multistep process that requires the action of fibroblasts, immune cells and a myriad of growth factors, cytokines and matrix components $[11,12]$.

During a sand fly blood meal significant damage occurs to the structure of skin, leading to rupture of the dermis and its capillaries, creating a blood "pool" containing ECM components from tissue and blood, and different cells as well $[13,14]$. This wound milieu at the dermis attracts macrophages, which are the main host cell type of Leishmania [15] and neutrophils as well [16]. Thus, a synchronized action mediated by promastigotes towards immune cells and ECM will be required for the establishment of the infection. Parasites will need to migrate in a very complex extracellular environment before being internalized by neutrophils or macrophages. Thus, the direct study of the interaction between Leishmania promastigotes and ECM components is an important step to understand the establishment of the infection.

Experimental leishmaniasis models have shown that collagen I, the major ECM component of the skin [17], is the predominant ECM component found in early stage lesions [18]. In vitro studies demonstrated the ability of promastigotes to attach to and move through collagen I scaffolds [19]. Attachment to collagen I occurred in a dose-dependent manner, indicating the presence of a parasite surface receptor [20]. Furthermore, parasite invasion on collagen I 3D scaffolds led to collagen remodeling (about $20 \%$ degradation), possibly mediated by metallo- and cysteine proteinases. Physical traits of the matrix, such as stiffness, decreased promastigote migration [19]. These observations may indicate that promastigotes need to secrete proteases to breakdown rigid collagen scaffolds to facilitate migration in the host before being internalized by a host cell. Interestingly, a collagen "shift" occurs during experimental infection with Leishmania: collagen I observed in early stages is substituted by collagen III during chronic phase of the infection [21]. It has been reported that decreased amounts of collagen III result in scar formation due to myofibroblast differentiation [22]. In contrast, a higher content of collagen III during leishmaniasis can induce the presence of a softer skin matrix, by which parasites would have an easier path for migration and tissue invasion. Promastigotes also bind to collagen VI, which is normally secreted by macrophages [23].

Fibronectin (FN), an adhesive glycoprotein found in the blood and connective tissues [24], is possibly found in sand fly mosquito bite lesions. An increase in FN expression in Leishmania-infected tissue has been observed in murine models [18]. Surface proteins from both promastigotes and amastigotes bind to FN, facilitating monocyte uptake, since these cells recognize FN [25]. Gp63 - a surface metalloproteinase - and cysteine proteases are able to degrade FN. These FN fragments inhibit macrophage formation of reactive oxygen species, which are important in clearance of the infection and also facilitate parasite and macrophage migration [5, 26], helped also by FN shedding [27]. Gp63, also is a FN-like molecule [28], which is recognized by macrophage integrin receptors contributing to parasite internalization [28]. A SYRD tetrapeptide from gp63 mimics the classic integrin recognition binding site RGDS [29], confirming its identity of FN-like molecule for this enzyme.

Another major group of ECM components present in the blood is the plasminogen/plasmin/fibrin system. Critical for coagulation, the blood clot also provides a provisional matrix by which neutrophils and macrophages migrate to during wound healing processes [30]. Promastigotes will need to escape from this fibrin structure, and at the same time allow target cells to get closer. Likewise, anti-coagulants found in the sand fly saliva are very important not only inhibiting blood coagulation but also counteracting promastigotes procoagulant activity [31]. The reason for this controlled balance of anti- and pro- coagulation molecules is still unknown, but it possibly gives to the dermal clot milieu the proper mechano-biochemical trigger for parasite cell invasion. It is known that Leishmania can bind to plasmin and plasminogen [32]. Enolase, a ubiquitous metabolic enzyme binds to plasminogen as a unique example of a multifunctional protein [33]. Promastigotes appear to secrete enolase in exocytic vesicles, which can help in immune evasion [34], since these vesicles have been implicated in parasite-macrophage communication. Furthermore, plasminogen-associated vesicles can trap macrophages, potentially allowing parasites to move further into the dermis.

The basement membrane (BM) is a fundamental structure in the skin. It separates the epithelium from the dermis and also surrounds blood capillaries. Sand fly bites locally disarrange BM structure, and promastigotes are exposed to its components: laminin, collagen IV, nidogen, and perlecan [14, 35]. Laminin is a family of glycoproteins that together with collagen IV form the general BM scaffold [36]. Leishmania promastigotes possess a cell surface $67 \mathrm{kDa}$ lamininbinding protein (LBP) [37], which is stimulated by zinc, suggesting a downstream signaling pathway [38]. This LBP appears to be important in Leishmania pathogenesis, since administration of anti-LBP antibodies reduce infectivity of $L$. donovani in mouse models [39]. Matrigel, a reconstituted basement membrane scaffold, has been used as substrate to study promastigote migration [5]. The role of the metalloproteinase gp63 on migration through and degradation of matrigel, was shown to be specifically related to collagen IV degradation, but not laminin $[5,40]$. 
Glycosaminoglycans are also components of mammalian ECM, usually associated with proteins, forming proteoglycans. They are present in the skin and can influence a variety of events during tissue repair, such as avoiding water lost, preventing tissue compression and regulating cell migration and survival [41]. Leishmania promastigotes bind to heparan sulfate, heparin and hyaluran [23], present at the dermal epithelial junction and the dermis. A heparin-binding protein, which mediates parasite - proteoglycan binding has been described and implicated in parasite virulence and host cell invasion, since Leishmania parasites were unable to invade cells without heparin on the surface. Also, parasite pre-treatment with heparin blocked binding to macrophages $[42,43]$.

The complexity of the ECM at the site of the sand fly bite increases when we take in consideration all the previously mentioned components in a dynamic setting containing cells. For instance, fibrosis formation mediated by fibroblasts can be a limiting situation for parasite propagation in the dermis. Thus, it is of interest to study cells not infected with Leishmania but present in the dermis microenvironment. Despite reports on Leishmania infection of fibroblasts [44-46], possibly the major issue is the remodeling of the collagen matrix by fibroblasts, due to growth factor stimulation coming from macrophages [12]. Complex macrophage -3D collagen I interaction system has been described, showing promastigotes migrating on collagen I scaffolds before being internalized by macrophages [19]. Furthermore, parasite migration is faster when macrophages are present [19], possibly indicating that secretion of cytokines can be chemotactic for Leishmania in complex in vitro invasion models.

The examples commented in this session are a reminder of how important the extracellular milieu can be critical for the pathogenesis of an infection caused by an intracellular pathogen such as Leishmania. Most of Leishmania/host cell studies use macrophages and neutrophils in suspended or 2D cultures, which does not reflect the complexity of the dermis during early stage leishmaniasis.

\section{Interaction between Leishmania and neutrophils}

Neutrophils are the first cells to migrate to infected sites, where they release antimicrobial mediators and phagocytose microorganisms, and kill infectious agents by generating a potent oxidative burst and releasing toxic mediators into the parasitophorous vacuole. The first studies on Leishmania-neutrophil interaction were published in 1981 [47-49], reporting the ability of human neutrophils to phagocytose and kill $L$. donovani promastigotes and amastigotes. Following these first reports, several aspects of the neutrophil-Leishmania interaction were studied, which were recently reviewed [50-54].
Here, we will address a recently described property of neutrophils, which is the ability to release their nuclear DNA associated with granular and cytoplasmic proteins to the extracellular milieu [55]. These structures, known as neutrophil extracellular traps (NETs), are released as a scaffold that ensnares and kills microorganisms. The NETs release culminates with a cell death process named NETosis, which is different from apoptosis and necrosis [56]. More recently, another NET release mechanism was described, in which nuclear budding vesicles carrying chromatin are extruded from neutrophils, releasing their contents in the extracellular milieu, where chromatin traps and kills pathogens [57]. This mechanism occurs preserving neutrophil viability and, thus, it was named "vital or early NETosis" to differentiate it from the classic NETosis associated with neutrophil death [58]. Therefore, it is important to address the role of NETosis in leishmaniasis, since the encounter of Leishmania and neutrophils is an early event when promastigotes are deposited in a pool of blood formed at the site of the sand fly bite, where neutrophils are abundant [59-65].

Several microorganisms induce NETosis [66] and, among parasites, L. amazonensis, L. major and $L$. infantum promastigotes [67] elicit the classical NETosis after in vitro interaction with human neutrophils. It is known that the majority of microorganisms induce the classical NETosis, which is dependent on reactive oxygen species (ROS) generated by NADPH oxidase, and of chromatin decondensation mediated by peptidylarginine deiminase 4 (PAD4), elastase and myeloperoxidase [56, 68-70]. It is only known that early NETosis, on the other hand, occurs quickly (5-15 $\mathrm{min}$ ) after inducer-neutrophil interaction and that it is independent of ROS generation $[57,58]$. Recently, we demonstrated that Leishmania promastigotes triggered both NETosis mechanisms, the classic one occurring with redox imbalance, PAD4 and elastase participation, and the early NETosis occurring in an elastase-dependent and ROS and PAD4-independent manner [71].

We have shown that $L$. amazonensis promastigotes were caught and killed by NETs in a histone-mediated mechanism [67]. The parasite death was evaluated by cell morphology in scanning electron microscopy and by quantifying promastigote survival in cultures with neutrophils in which DNase was added to disrupt NET-DNA mediated death [67]. Although the mechanism of histone-mediated cell death is still unknown, histone toxicity has been demonstrated for to promastigotes of L. mexicana, L. braziliensis, L. major and L. amazonensis, but histone resistance has been reported for amastigotes of $L$. mexicana and $L$. amazonensis [72]. Interestingly, $L$. donovani promastigotes induced NET extrusion by human neutrophils, although they were resistant to NET mediated killing, protected by 
the lipophosphoglycan (LPG) expressed on the promastigote cell surface, since LPG-knockout parasites were susceptible to the NET-killing mechanism [73]. In contrast to $L$. donovani LPG, purified L. amazonensis LPG triggered NETosis [67], a difference that could be due to the interand intra-specific polymorphisms found in this molecule of different Leishmania species [74, 75].

More recently, it has been demonstrated that $L$. mexicana induced NETosis in mice neutrophils in vitro, and NETs were observed in the ear of mice inoculated with this same parasite. Interestingly, these NETs did not kill L. mexicana promastigotes [65].

Properties already assigned to NETs include trapping to avoid pathogen spreading, phagocytosis assistance through its trapping activity, and killing of microorganisms. Microbes have also evolved different strategies to escape NETs toxic mechanisms. Accordingly, a conserved bacterial tool to escape NET toxicity is the expression of nucleases, which efficiently degrade NET-DNA scaffolds, neutralizing their toxic effects and allowing bacterial spread throughout the body [76-84]. Interestingly, Leishmania promastigotes express 3'-nucleotidase/nuclease, a class I nuclease member, which cleaves NET-DNA, allowing parasites to escape NET-trapping and -killing [85]. Furthermore, the Lutzomyia longipalpis sand fly saliva inoculated into the host skin together with Leishmania promastigotes, contains the powerful endonuclease Lutzomyia NET destroying protein (Lundep), that degrades NET-DNA meshes, allowing parasites to escape NET-toxic activity and exacerbates Leishmania infection [86]. The evolutionary conservation of NET induction ability into different Leishmania spp., points to the possibility that NETosis occurs during parasite transmission to the vertebrate host; however, NETs toxicity might be counteracted by the activity of promastigote nucleases, as well as by the presence of endonuclease in the vector's saliva. Importantly, not only promastigotes induce NETosis, since amastigote forms also trigger NETs in vitro [62], and amastigote nests were found associated with NETs in lesions of human American tegumentary leishmaniasis [87]. The study of the Leishmania ability to induce NET release could advance the understanding of the early aspects of the innate immunity to this protozoan and of the pathogenesis of Leishmania infection as well.

Interaction between Leishmania and macrophages Leishmania promastigotes are rapidly phagocytized by neutrophils and macrophages after being inoculated by the sand fly vector. Although Leishmania is mainly found in neutrophils during the first hours of infection, the parasites do not differentiate into amastigotes inside these cells, but in macrophages. Thus, macrophages are important for the establishment of infection and persistence of the parasite inside the host $[64,88]$. In addition, it has been previously reported that upon phagocytosis of Leishmania major, mononuclear phagocytes harboring live parasites migrate from the skin to the draining lymph node of the host [89-91]. Macrophage migration is dependent on the interaction of these cells with the ECM [92], although the mechanisms involved in this process during Leishmania infection remains unknown. The capacity of these cells to home to the skin, to mucosae, or to internal organs may also be modulated by the parasite [93] and can play an important role in the dissemination of the disease.

Studies using $L$. mexicana and L. infantum have shown that molecules like proteophosphoglycans secreted by these parasites in the sand fly's midgut and inoculated into the host during blood meal are powerful stimulators of macrophage recruitment [94, 95]. During the initial recognition events, different species of Leishmania rely on a range of macrophage receptors, including complement receptors (CRs), mannose receptors (MR), fibronectin receptors and $\mathrm{F} c \gamma$ receptors ( $\mathrm{Fc} \gamma \mathrm{Rs}$ ), which may later impact the course of infection $[28,96-101]$. Although reports in the literature have claimed that these routes of parasite entry are redundant, the ligation of specific receptors elicits different downstream functions in the macrophage [28, 96-101]. It was shown that avirulent promastigotes in logarithmic growth enter parasitophorous vacuoles lined with CR3 and MR, whereas PVs surrounding densitypurified metacyclics contained only CR3 [102]. CR3, but not MR, clusters in cholesterol- and caveolin-containing microdomains, which were previously characterized as entry routes that direct $L$. infantum promastigotes into a pathway that leads to a 24- to 48-h delay in lysosomal fusion and allows better replication of parasites, leading to intracellular survival [103].

Once the parasite is recognized by the macrophage, focal exocytosis of host cell membrane originating from endosomes, lysosomes and the endoplasmic reticulum contribute to the formation of the promastigotecontaining phagosomes [104-106]. Such supply of membrane from various intracellular compartments may contribute to the formation and the composition of the nascent parasitophorous vacuole. Other factors during the initial moments of the infection have an important role in determining the establishment of the disease, such as the sand fly saliva. Leishmania parasites as well as sand fly saliva have been associated with suppression of the initial proinflammatory immune response, promoting parasite survival [107-111]. Co-injection of saliva or its components together with Leishmania were shown to exacerbate cutaneous leishmaniasis, producing larger lesions and a higher parasite burden. This enhancement in Leishmania lesions by saliva was attributed to the immunomodulatory properties of the salivary proteins, which act in the initial moments of the infection, promoting downregulation of macrophage and 
dendritic cell functions and the production of antiinflammatory cytokines that favor parasite survival and establishment [112-116]. It has been shown that the increase in infectivity was associated with the ability of the saliva to selectively inhibit pathogen recognition, nitric oxide (NO) and hydrogen peroxide production thus, inhibiting the ability of macrophages to kill the parasites $[117,118]$. Furthermore, it was also shown that Leishmania vector saliva inhibits the production of protective type 1 cytokines such as IL-12 and IFN- $\gamma$, while enhancing the production of IL-10, IL-4, IL-6 and prostaglandin $\mathrm{E}(\mathrm{PGE})_{2}$, all of which enhance parasite survival $[108,119,120]$.

After the inoculation and initial infection, Leishmania parasites may remain at the inoculation site or disseminate in the host tissues. Although the mechanisms that control Leishmania dissemination through different host tissues are poorly understood, the initial events that occur at the site of infection have an important role in this process. Evidence suggests that Leishmania infection and the parasite burden modulate the adhesion and migratory capability of mononuclear phagocytes [121, 122]. Carvalhal and coworkers [121] demonstrated that infection with different Leishmania species impairs the adherence of monocytes and macrophages to connective tissue. Such impairment in leukocyte adhesion is due to interference with integrin function, as the authors demonstrated a regulation in cell surface $\beta 1$-integrin activity in infected macrophages [123]. Furthermore, infection with Leishmania downregulates the expression of the genes encoding the chemokine receptors CCR4 and CCR5 in murine dendritic cells. The impairment of chemokine production can be related to reduced migration of phagocytes from the parasite inoculation site and could interfere with the development of a systemic/adaptive response [121, 122]. In addition, it has been shown recently that leukocyte spreading over a fibronectin-coated surface is abrogated in Leishmania-infected cells [124]. These changes in the initial moments of the infection and in phagocyte function may be important for parasite dissemination and distribution of lesions in leishmaniasis.

\section{Conclusions}

Although long viewed only as a supportive structure, the ECM is an essential part of the cell's milieu that regulates almost all cellular behavior [125], including inflammatory signaling [126]. In leishmaniasis, once Leishmania parasites are inoculated in the host's skin, they will need to migrate in a very complex extracellular environment before being internalized by neutrophils and/or macrophages, which are also responding to a complex wound tissue microenvironment.

Challenges remain in understanding leishmanial biology and how this parasite interacts with the host tissue.
However, in the last few years, it seems clear that the initial interaction between Leishmania parasites and the host extracellular matrix and immune cells, such as neutrophils and macrophages, has an important role on the determination of Leishmania infection outcome. Promastigote ECM migration, fibroblast wound response, macrophage migration, and NET formation can be critical emergent topics for the full understanding of Leishmania pathogenesis.

\section{Competing interests}

The authors declare that they have no competing interests.

\section{Authors' contributions}

JM, ES and BRA wrote and revised the manuscript in its entirety. All authors read and approved the final version of this manuscript.

\section{Acknowledgements}

We thank Prof. Francine Marciano-Cabral (Virginia Commonwealth University) for reviewing this manuscript and CAPES-MEC, CNPq, Programa Ciências Sem Fronteiras, CPqGM-FIOCRUZ, and FAPERJ for the financial support. BRA is a Young Talent Fellow from Science Without Frontiers Program, CAPES-MEC (CsF/BJT - 88887.091752/2014-00).

\section{Author details}

${ }^{1}$ Gonçalo Muniz Research Center, Oswaldo Cruz Foundation (FIOCRUZ), Salvador, Brazil. Departamento de Imunologia, Instituto de Microbiologia Paulo de Góes, Universidade Federal do Rio de Janeiro (UFRJ), Rio de Janeiro, Brazil. ${ }^{3}$ Programa de Terapia Celular e Bioengenharia, Instituto de Biofísica Carlos Chagas Filho, Universidade Federal do Rio de Janeiro (UFRJ), Rio de Janeiro, Brazil. ${ }^{4}$ Present Address: Department of Biophysics, The University of Texas Southwestern Medical Center, 5323 Harry Hines Boulevard, Dallas, TX 75390, USA.

Received: 1 March 2016 Accepted: 26 April 2016

Published online: 04 May 2016

\section{References}

1. Rogers ME, Chance ML, Bates PA. The role of promastigote secretory gel in the origin and transmission of the infective stage of Leishmania mexicana by the sandfly Lutzomyia longipalpis. Parasitol England. 2002;124:495-507.

2. Milon G. Perpetuation of Leishmania: some novel insight into elegant developmental programs. Vet Res France. 2009;40:38.

3. Moreno I, Dominguez M, Cabanes D, Aizpurua C, Torano A. Kinetic analysis of ex vivo human blood infection by Leishmania. PLoS Negl Trop Dis United States. 2010:4:e743.

4. Kaye P, Scott P. Leishmaniasis: complexity at the host-pathogen interface. Nat Rev Microbiol Engl. 2011;9:604-15.

5. McGwire BS, Chang KP, Engman DM. Migration through the extracellular matrix by the parasitic protozoan Leishmania is enhanced by surface metalloprotease gp63. Infect Immun. 2003;71:1008-10.

6. Nelson CM, Bissell MJ. Of extracellular matrix, scaffolds, and signaling: tissue architecture regulates development, homeostasis, and cancer. Annu Rev Cell Dev Biol United States. 2006;22:287-309.

7. Xu R, Boudreau A, Bissell MJ. Tissue architecture and function: dynamic reciprocity via extra- and intra-cellular matrices. Cancer Metastasis Rev Netherlands. 2009;28:167-76.

8. Berrier AL, Yamada KM. Cell-matrix adhesion. J Cell Physiol United States. 2007;213:565-73.

9. Pickup MW, Mouw JK, Weaver VM. The extracellular matrix modulates the hallmarks of cancer. EMBO Rep Engl. 2014;15:1243-53.

10. Grinnell F. Fibroblast biology in three-dimensional collagen matrices. Trends Cell Biol Engl. 2003;13:264-9.

11. Watt FM, Fujiwara H. Cell-extracellular matrix interactions in normal and diseased skin. Cold Spring Harb Perspect Biol. 2011;3:a005124.

12. Singer AJ, Clark RA. Cutaneous wound healing. N Engl J Med United States. 1999;341:738-46.

13. Ribeiro JM. Vector salivation and parasite transmission. Mem Inst Oswaldo Cruz Brazil. 1987;82 Suppl 3:1-3. 
14. de Almeida MC, Vilhena V, Barral A, Barral-Netto M. Leishmanial infection: analysis of its first steps. Rev Mem Inst Oswaldo Cruz Brazil. 2003:98:861-70.

15. Arango Duque $G$, Descoteaux A. Leishmania survival in the macrophage: where the ends justify the means. Curr Opin Microbiol Engl. 2015;26:32-40.

16. Ribeiro-Gomes FL, Otero AC, Gomes NA, Moniz-De-Souza MCA, CysneFinkelstein L, Arnholdt AC, et al. Macrophage interactions with neutrophils regulate Leishmania major infection. J Immunol United States. 2004;172: 4454-62.

17. Wells A, Nuschke A, Yates CC. Skin tissue repair: Matrix microenvironmental influences. Matrix Biol. 2015;49:25-36.

18. Silva Almeida M, Carvalho LO, Abreu Silva AL, Souza CS, Hardoim DJ, Calabrese KS. Extracellular matrix alterations in experimental Leishmania amazonensis infection in susceptible and resistant mice. Vet Res [Internet]. 2012;43:10. Available from: http://www.ncbi.nlm.nih.gov/pubmed/22316002.

19. Petropolis DB, Rodrigues JCF, Viana NB, Pontes B, Pereira CFA, Silva Filho FC. Leishmania amazonensis promastigotes in 3D Collagen I culture: an in vitro physiological environment for the study of extracellular matrix and host cell interactions. PeerJ [Internet]. 2014;2:e317. Available from: https://peerj.com/ articles/317.

20. Lira R, Rosales-Encina JL, Arguello C. Leishmania mexicana: binding of promastigotes to type I collagen. Exp Parasitol United States. 1997:85:149-57.

21. Abreu-Silva AL, Calabrese KS, Mortara RA, Tedesco RC, Cardoso FO, Carvalho LOP, et al. Extracellular matrix alterations in experimental murine Leishmania (L.) amazonensis infection. Parasitology. England. 2004;128:385-90.

22. Volk SW, Wang Y, Mauldin EA, Liechty KW, Adams SL. Diminished type III collagen promotes myofibroblast differentiation and increases scar deposition in cutaneous wound healing. Cells Tissues Organs Switzerland. 2011;194:25-37.

23. Fatoux-Ardore M, Peysselon F, Weiss A, Bastien P, Pratlong F, Ricard-Blum S. Large-scale investigation of Leishmania interaction networks with host extracellular matrix by surface plasmon resonance imaging. Infect Immun United States. 2014;82:594-606.

24. Pankov R, Yamada KM. Fibronectin at a glance. J Cell Sci Engl. 2002;115: 3861-3

25. Wyler DJ, Sypek JP, McDonald JA. In vitro parasite-monocyte interactions in human leishmaniasis: possible role of fibronectin in parasite attachment. Infect Immun United States. 1985:49:305-11.

26. Kulkarni MM, Jones EA, McMaster WR, McGwire BS. Fibronectin binding and proteolytic degradation by Leishmania and effects on macrophage activation. Infect Immun United States. 2008;76:1738-47.

27. Vannier-Santos MA, Saraiva EM, Martiny A, Neves A, de Souza W. Fibronectin shedding by Leishmania may influence the parasite-macrophage interaction. Eur J Cell Biol Germany. 1992;59:389-97.

28. Brittingham A, Chen G, McGwire BS, Chang KP, Mosser DM. Interaction of Leishmania gp63 with cellular receptors for fibronectin. Infect Immun United States. 1999;67:4477-84.

29. Soteriadou KP, Remoundos MS, Katsikas MC, Tzinia AK, Tsikaris V, Sakarellos C, et al. The Ser-Arg-Tyr-Asp region of the major surface glycoprotein of Leishmania mimics the Arg-Gly-Asp-Ser cell attachment region of fibronectin. J Biol Chem United States. 1992;267:13980-5.

30. Shaw TJ, Martin P. Wound repair at a glance. J Cell Sci Engl. 2009;122:3209-13.

31. Rochael NC, Lima LG, de Oliveira SMP, Barcinski MA, Saraiva EM, Monteiro $\mathrm{RQ}$, et al. Leishmania amazonensis exhibits phosphatidylserine-dependent procoagulant activity, a process that is counteracted by sandfly saliva. Mem Inst Oswaldo Cruz Brazil. 2013;108:679-85.

32. Avilan L, Calcagno M, Figuera M, Lemus L, Puig J, Rodriguez AM. Interaction of Leishmania mexicana promastigotes with the plasminogen-plasmin system. Mol Biochem Parasitol Netherlands. 2000;110:183-93.

33. Vanegas G, Quinones W, Carrasco-Lopez C, Concepcion JL, Albericio F, Avilan L. Enolase as a plasminogen binding protein in Leishmania mexicana. Parasitol Res Germany. 2007;101:1511-6.

34. Figuera L, Acosta H, Gomez-Arreaza A, Davila-Vera D, Balza-Quintero A, Quinones W, et al. Plasminogen binding proteins in secreted membrane vesicles of Leishmania mexicana. Mol Biochem Parasitol Netherlands. 2013;187:14-20.

35. Kalluri R. Basement membranes: structure, assembly and role in tumour angiogenesis. Nat Rev Cancer Engl. 2003;3:422-33.

36. Hohenester E, Yurchenco PD. Laminins in basement membrane assembly. Cell Adh Migr United States. 2013;7:56-63.

37. Ghosh A, Bandyopadhyay K, Kole L, Das PK. Isolation of a laminin-binding protein from the protozoan parasite Leishmania donovani that may mediate cell adhesion. Biochem J Engl. 1999;337:551-8. Pt 3.
38. Bandyopadhyay K, Karmakar S, Ghosh A, Das PK. High affinity binding between laminin and laminin binding protein of Leishmania is stimulated by zinc and may involve laminin zinc-finger like sequences. Eur J Biochem Germany. 2002;269:1622-9.

39. Bandyopadhyay K, Karmakar S, Ghosh A, Das PK. Role of 67 kDa cell surface laminin binding protein of Leishmania donovani in pathogenesis. J Biochem Japan. 2001;130:141-8.

40. Yao C, Donelson JE, Wilson ME. Internal and surface-localized major surface proteases of Leishmania spp. and their differential release from promastigotes. Eukaryot Cell United States. 2007;6:1905-12.

41. Salbach J, Rachner TD, Rauner M, Hempel U, Anderegg U, Franz S, et al. Regenerative potential of glycosaminoglycans for skin and bone (Berl). J Mol Med Germany. 2012;90:625-35.

42. Butcher BA, Sklar LA, Seamer LC, Glew RH. Heparin enhances the interaction of infective Leishmania donovani promastigotes with mouse peritoneal macrophages. A fluorescence flow cytometric analysis. J Immunol United States. 1992:148:2879-86.

43. Love DC, Esko JD, Mosser DM. A heparin-binding activity on Leishmania amastigotes which mediates adhesion to cellular proteoglycans. J Cell Biol United States. 1993;123:759-66.

44. Chang KP. Dwyer DM. Leishmania donovani. Hamster macrophage interactions in vitro: cell entry, intracellular survival, and multiplication of amastigotes. J Exp Med United States. 1978;147:515-30.

45. Schwartzman JD, Pearson RD. The interaction of Leishmania donovani promastigotes and human fibroblasts in vitro. Am J Trop Med Hyg United States. 1985;34:850-5.

46. Bogdan C, Donhauser N, Doring R, Rollinghoff M, Diefenbach A, Rittig MG Fibroblasts as host cells in latent leishmaniosis. J Exp Med United States. 2000;191:2121-30

47. Chang KP. Antibody-mediated inhibition of phagocytosis in Leishmania donovani-human phagocyte interactions in vitro. Am J Trop Med Hyg United States. 1981:30:334-9.

48. Chang KP. Leishmanicidal mechanisms of human polymorphonuclear phagocytes. Am J Trop Med Hyg United States. 1981;30:322-33.

49. Pearson RD, Steigbigel RT. Phagocytosis and killing of the protozoan Leishmania donovani by human polymorphonuclear leukocytes. J Immunol United States. 1981;127:1438-43.

50. Carlsen ED, Liang Y, Shelite TR, Walker DH, Melby PC, Soong L. Permissive and protective roles for neutrophils in leishmaniasis. Clin Exp Immunol Engl. 2015;182:109-18.

51. Filardy AA, Pires DR, DosReis GA. Macrophages and neutrophils cooperate in immune responses to Leishmania infection. Cell Mol Life Sci Switzerland. 2011;68:1863-70.

52. Ribeiro Gomes FL, Sacks D. The influence of early neutrophil-Leishmania interactions on the host immune response to infection. Front Cell Infect Microbiol Switzerland. 2012;2:59.

53. Schuster S, Hurrell B, Tacchini-Cottier F. Crosstalk between neutrophils and dendritic cells: a context-dependent process. J Leukoc Biol United States. 2013;94:671-5.

54. Soong L, Henard CA, Melby PC. Immunopathogenesis of non-healing American cutaneous leishmaniasis and progressive visceral leishmaniasis. Semin Immunopathol Germany. 2012;34:735-51.

55. Brinkmann V, Reichard U, Goosmann C, Fauler B, Uhlemann Y, Weiss DS, et al. Neutrophil extracellular traps kill bacteria. Science United States. 2004; 303:1532-5

56. Fuchs TA, Abed U, Goosmann C, Hurwitz R, Schulze I, Wahn V, et al. Novel cell death program leads to neutrophil extracellular traps. J Cell Biol United States. 2007;176:231-41.

57. Pilsczek FH, Salina D, Poon KKH, Fahey C, Yipp BG, Sibley CD, et al. A novel mechanism of rapid nuclear neutrophil extracellular trap formation in response to Staphylococcus aureus. J Immunol United States. 2010;185:7413-25.

58. Yipp BG, Kubes P. NETosis: how vital is it? Blood United States. 2013:122:2784-94.

59. Wilson E, Rice WG, Kinkade JMJ, Merrill AHJ, Arnold RR, Lambeth JD. Protein kinase $C$ inhibition by sphingoid long-chain bases: effects on secretion in human neutrophils. Arch Biochem Biophys United States. 1987;259:204-14.

60. Pompeu ML, Freitas LA, Santos ML, Khouri M, Barral Netto M. Granulocytes in the inflammatory process of BALB/C mice infected by Leishmania amazonensis. Quantitative Approach Acta Trop Netherlands. 1991:48:185-93.

61. Beil WJ, Meinardus-Hager G, Neugebauer DC, Sorg C. Differences in the onset of the inflammatory response to cutaneous leishmaniasis in resistant and susceptible mice. J Leukoc Biol United States. 1992;52:135-42. 
62. Belkaid Y, Kamhawi S, Modi G, Valenzuela J, Noben-Trauth N, Rowton E, et al. Development of a natural model of cutaneous leishmaniasis: powerful effects of vector saliva and saliva preexposure on the long-term outcome of Leishmania major infection in the mouse ear dermis. J Exp Med United States. 1998;188:1941-53.

63. Tacchini-Cottier F, Zweifel C, Belkaid Y, Mukankundiye C, Vasei M, Launois $P$, et al. An immunomodulatory function for neutrophils during the induction of a CD4+ Th2 response in BALB/C mice infected with Leishmania major. J Immunol United States. 2000;165:2628-36.

64. Peters NC, Sacks DL. The impact of vector-mediated neutrophil recruitment on cutaneous leishmaniasis. Cell Microbiol [Internet]. 2009;11:1290-6. Available from: http://www.ncbi.nlm.nih.gov/pubmed/19545276.

65. Hurrell BP, Schuster S, Grun E, Coutaz M, Williams RA, Held W, et al. Rapid sequestration of Leishmania mexicana by neutrophils contributes to the development of chronic lesion. PLoS Pathog United States. 2015;11:e1004929.

66. Guimaraes Costa AB, Nascimento MTC, Wardini AB, Pinto Da Silva LH, Saraiva EM. ETosis: a microbicidal mechanism beyond cell death. J Parasitol Res United States. 2012;2012:929743.

67. Guimaraes-Costa AB, Nascimento MTC, Froment GS, Soares RPP, Morgado $\mathrm{FN}$, Conceicao-Silva $\mathrm{F}$, et al. Leishmania amazonensis promastigotes induce and are killed by neutrophil extracellular traps. Proc Natl Acad Sci U S A United States. 2009;106:6748-53.

68. Kirchner T, Moller S, Klinger M, Solbach W, Laskay T, Behnen M. The impact of various reactive oxygen species on the formation of neutrophil extracellular traps. Mediators Inflamm United States. 2012;2012:849136.

69. Papayannopoulos V, Metzler KD, Hakkim A, Zychlinsky A. Neutrophil elastase and myeloperoxidase regulate the formation of neutrophil extracellular traps. J Cell Biol United States. 2010;191:677-91.

70. Wang Y, Li M, Stadler S, Correll S, Li P, Wang D, et al. Histone hypercitrullination mediates chromatin decondensation and neutrophil extracellular trap formation. J Cell Biol United States. 2009;184:205-13.

71. Rochael NC, Guimaraes Costa AB, Nascimento MTC, DeSouza Vieira TS, Oliveira MP, Souza LF GE, et al. Classical ROS-dependent and early/rapid ROS-independent release of Neutrophil Extracellular Traps triggered by Leishmania parasites. Sci Rep Engl. 2015;5:18302.

72. Wang Y, Chen Y, Xin L, Beverley SM, Carlsen ED, Popov V, et al. Differential microbicidal effects of human histone proteins $\mathrm{H} 2 \mathrm{~A}$ and $\mathrm{H} 2 \mathrm{~B}$ on Leishmania promastigotes and amastigotes. Infect Immun United States. 2011;79:1124-33.

73. Gabriel C, McMaster WR, Girard D, Descoteaux A. Leishmania donovani promastigotes evade the antimicrobial activity of neutrophil extracellular traps. J Immunol United States. 2010;185:4319-27.

74. Mahoney AB, Sacks DL, Saraiva E, Modi G, Turco SJ. Intra-species and stagespecific polymorphisms in lipophosphoglycan structure control Leishmania donovani-sand fly interactions. Biochem United States. 1999;38:9813-23.

75. Forestier CL, Gao Q, Boons GJ. Leishmania lipophosphoglycan: how to establish structure-activity relationships for this highly complex and multifunctional glycoconjugate? Front Cell Infect Microbiol Switzerland. 2014;4:193.

76. Beiter K, Wartha F, Albiger B, Normark S, Zychlinsky A, Henriques-Normark B. An endonuclease allows Streptococcus pneumoniae to escape from neutrophil extracellular traps. Curr Biol Engl. 2006;16:401-7.

77. Buchanan JT, Simpson AJ, Aziz RK, Liu GY, Kristian SA, Kotb M, et al. DNase expression allows the pathogen group A Streptococcus to escape killing in neutrophil extracellular traps. Curr Biol Engl. 2006;16:396-400.

78. Berends ETM, Horswill AR, Haste NM, Monestier M, Nizet V, von KockritzBlickwede M. Nuclease expression by Staphylococcus aureus facilitates escape from neutrophil extracellular traps. J Innate Immun Switzerland. 2010;2:576-86.

79. Derre-Bobillot A, Cortes-Perez NG, Yamamoto Y, Kharrat P, Couve E, Da Cunha $V$, et al. Nuclease A (Gbs0661), an extracellular nuclease of Streptococcus agalactiae, attacks the neutrophil extracellular traps and is needed for full virulence. Mol Microbiol Engl. 2013;89:518-31.

80. Seper A, Hosseinzadeh A, Gorkiewicz G, Lichtenegger S, Roier S, Leitner DR, et al. Vibrio cholerae evades neutrophil extracellular traps by the activity of two extracellular nucleases. PLoS Pathog United States. 2013;9:e1003614.

81. de Buhr N, Neumann A, Jerjomiceva N, von Kockritz-Blickwede M, Baums CG. Streptococcus suis DNase SsnA contributes to degradation of neutrophil extracellular traps (NETs) and evasion of NET-mediated antimicrobial activity. Microbiol Engl. 2014;160:385-95.

82. Thammavongsa V, Missiakas DM, Schneewind O. Staphylococcus aureus degrades neutrophil extracellular traps to promote immune cell death. Science United States. 2013;342:863-6.
83. Morita C, Sumioka R, Nakata M, Okahashi N, Wada S, Yamashiro T, et al. Cell wall-anchored nuclease of Streptococcus sanguinis contributes to escape from neutrophil extracellular trap-mediated bacteriocidal activity. PLoS One United States. 2014;9:e103125.

84. Juneau RA, Stevens JS, Apicella MA, Criss AK. A thermonuclease of Neisseria gonorrhoeae enhances bacterial escape from killing by neutrophil extracellular traps. J Infect Dis United States. 2015;212:316-24.

85. Guimaraes-Costa AB, DeSouza-Vieira TS, Paletta-Silva R, Freitas-Mesquita AL, Meyer-Fernandes JR, Saraiva EM. 3'-nucleotidase/nuclease activity allows Leishmania parasites to escape killing by neutrophil extracellular traps. Infect Immun United States. 2014:82:1732-40.

86. Chagas AC, Oliveira F, Debrabant A, Valenzuela JG, Ribeiro JMC, Calvo E. Lundep, a sand fly salivary endonuclease increases Leishmania parasite survival in neutrophils and inhibits Xlla contact activation in human plasma. PLoS Pathog United States. 2014;10:e1003923.

87. Morgado FN, Nascimento MTC, Saraiva EM, De Oliveira Ribeiro C, Madeira M, De F, Da Costa Santos M. Are neutrophil extracellular traps playing a role in the parasite control in active American tegumentary leishmaniasis lesions? PLoS One. United States. 2015;10:e0133063.

88. Beattie L, Kaye PM. Leishmania-host interactions: what has imaging taught us? Cell Microbiol [Internet]. 2011;13:1659-67. Available from: http://www. ncbi.n/m.nih.gov/pubmed/21819514.

89. Moll H, Fuchs $H$, Blank C, Röllinghoff M. Langerhans cells transport Leishmania major from the infected skin to the draining lymph node for presentation to antigen-specific T cells. Eur J Immunol [Internet]. 1993;23: 1595-601. [cited 2016 Apr 13]Available from: http://www.ncbi.nlm.nih.gov/ pubmed/8325337.

90. Muraille E, De Trez C, Pajak B, Torrentera FA, De Baetselier P, Leo O, et al. Amastigote load and cell surface phenotype of infected cells from lesions and lymph nodes of susceptible and resistant mice infected with Leishmania major. Infect Immun [Internet]. 2003;71:2704-15. [cited 2016 Apr 13]. Available from: http://www.ncbi.n/m.nih.gov/pubmed/12704145.

91. Ritter U, Meissner A, Scheidig C, Körner H. CD8 alpha- and Langerin-negative dendritic cells, but not Langerhans cells, act as principal antigen-presenting cells in leishmaniasis. Eur J Immunol [Internet]. 2004;34:1542-50. [cited 2016 Apr 13]. Available from: http://www.ncbi.nlm.nih.gov/pubmed/15162423.

92. Wiesner C, Le Cabec V, El Azzouzi K, Maridonneau Parini I, Linder S. Podosomes in space: macrophage migration and matrix degradation in 2D and 3D settings. Cell Adh Migr [Internet]. 2014;8:179-91. [cited 2016 Apr 13] Available from: http://www.ncbi.n/m.nih.gov/pubmed/24713854.

93. Belhadj S, Pratlong F, Toumi NH, Kallel K, Mahjoub H, Babba H, et al. Visceral leishmaniasis in Tunisia: result of the isoenzymatic characterization of 65 Leishmania infantum strains. Trans R Soc Trop Med Hyg [Internet]. 2016;96: 627-30. [cited 2016 Apr 13]. Available from: http://www.ncbi.nlm.nih.gov/ pubmed/12625137.

94. Rogers $M$, Kropf $P$, Choi BS, Dillon R, Podinovskaia M, Bates $P$, et al. Proteophosophoglycans regurgitated by Leishmania-infected sand flies target the L-arginine metabolism of host macrophages to promote parasite survival. PLoS Pathog [Internet]. 2009:5:e1000555. Available from: http:// www.ncbi.nlm.nih.gov/pubmed/19696894

95. Rogers ME, Corware K, Muller I, Bates PA. Leishmania infantum proteophosphoglycans regurgitated by the bite of its natural sand fly vector, Lutzomyia longipalpis, promote parasite establishment in mouse skin and skin-distant tissues. Microbes Infect [Internet]. 2010;12:875-9. Available from: http://www.ncbi.nlm.nih.gov/pubmed/20561596.

96. Ueno N, Wilson ME. Receptor-mediated phagocytosis of Leishmania: implications for intracellular survival. Trends Parasitol [Internet]. 2012;28:33544. Available from: http://www.ncbi.nlm.nih.gov/pubmed/22726697.

97. Mosser DM, Edelson PJ. Activation of the alternative complement pathway by Leishmania promastigotes: parasite lysis and attachment to macrophages. J Immunol United States. 1984;132:1501-5.

98. Brittingham A, Mosser DM. Exploitation of the complement system by Leishmania promastigotes. Parasitol Today Engl. 1996;12:444-7.

99. Guy RA, Belosevic M. Comparison of receptors required for entry of Leishmania major amastigotes into macrophages. Infect Immun United States. 1993;61:1553-8.

100. Blackwell JM, Ezekowitz RA, Roberts MB, Channon JY, Sim RB, Gordon S Macrophage complement and lectin-like receptors bind Leishmania in the absence of serum. J Exp Med United States. 1985;162:324-31.

101. Wilson ME, Pearson RD. Roles of CR3 and mannose receptors in the attachment and ingestion of Leishmania donovani by human mononuclear phagocytes. Infect Immun United States. 1988;56:363-9. 
102. Ueno N, Bratt CL, Rodriguez NE, Wilson ME. Differences in human macrophage receptor usage, lysosomal fusion kinetics and survival between logarithmic and metacyclic Leishmania infantum chagasi promastigotes. Cell Microbiol [Internet]. 2009;11:1827-41. [cited 2016 Apr 13]. Available from: http://www.ncbi.nlm.nih.gov/pubmed/19702651.

103. Rodríguez NE, Gaur U, Wilson ME. Role of caveolae in Leishmania chagasi phagocytosis and intracellular survival in macrophages. Cell Microbiol [Internet]. 2006;8:1106-20. [cited 2016 Apr 13]. Available from: http://www. ncbi.nlm.nih.gov/pubmed/16819964.

104. Gagnon E, Duclos S, Rondeau C, Chevet E, Cameron PH, Steele Mortimer O, et al. Endoplasmic reticulum-mediated phagocytosis is a mechanism of entry into macrophages. Cell [Internet]. 2002;110:119-31. Available from: http://www.ncbi.nlm.nih.gov/pubmed/12151002

105. Vinet AF, Fukuda M, Turco SJ, Descoteaux A. The Leishmania donovani lipophosphoglycan excludes the vesicular proton-ATPase from phagosomes by impairing the recruitment of synaptotagmin V. PLoS Pathog [Internet]. 2009;5:e1000628. Available from: http://www.ncbi.nlm.nih.gov/pubmed/ 19834555.

106. Forestier CL, Machu C, Loussert C, Pescher P, Spath GF. Imaging host cellLeishmania interaction dynamics implicates parasite motility, lysosome recruitment, and host cell wounding in the infection process. Cell Host Microbe [Internet]. 2011;9:319-30. Available from: http://www.ncbi.nlm.nih gov/pubmed/21501831.

107. De Moura TR, Oliveira F, Rodrigues GC, Carneiro MW, Fukutani KF, Novais FO, et al. Immunity to Lutzomyia intermedia saliva modulates the inflammatory environment induced by Leishmania braziliensis. PLoS Negl Trop Dis [Internet]. 2010;4:e712. Available from: http://www.ncbi.nIm.nih. gov/pubmed/20559550.

108. Carregaro V, Costa DL, Brodskyn C, Barral AM, Barral Netto M, Cunha FQ, et al. Dual effect of Lutzomyia longipalpis saliva on Leishmania braziliensis infection is mediated by distinct saliva-induced cellular recruitment into BALB/c mice ear. BMC Microbiol [Internet]. 2013;13:102. Available from: http://www.ncbi.nlm.nih.gov/pubmed/23656976.

109. Andrade BB, De Oliveira Cl, Brodskyn Cl, Barral A, Barral Netto M. Role of sand fly saliva in human and experimental leishmaniasis: current insights. Scand J Immunol [Internet]. 2007;66:122-7. Available from: http://www.ncbi. nlm.nih.gov/pubmed/17635789.

110. Ribeiro Gomes FL, Peters NC, Debrabant A, Sacks DL. Efficient capture of infected neutrophils by dendritic cells in the skin inhibits the early antileishmania response. PLoS Pathog [Internet]. 2012;8:e1002536. Available from: http://www.ncbi.n/m.nih.gov/pubmed/22359507.

111. Liu D, Uzonna JE. The early interaction of Leishmania with macrophages and dendritic cells and its influence on the host immune response. Front Cell Infect Microbiol [Internet]. 2012;2:83. Available from: http://www.ncbi. nlm.nih.gov/pubmed/22919674.

112. Qureshi AA, Asahina A, Ohnuma M, Tajima M, Granstein RD, Lerner EA. Immunomodulatory properties of maxadilan, the vasodilator peptide from sand fly salivary gland extracts. Am J Trop Med Hyg [Internet]. 1996;54:66571. Available from: http://www.ncbi.n/m.nih.gov/pubmed/8686790.

113. Mbow ML, Bleyenberg JA, Hall LR, Titus RG. Phlebotomus papatasi sand fly salivary gland lysate down-regulates a Th1, but up-regulates a Th2, response in mice infected with Leishmania major. J Immunol [Internet]. 1998;161: 5571-7. Available from: http://www.ncbi.nlm.nih.gov/pubmed/9820534.

114. Rogers KA, Titus RG. Immunomodulatory effects of Maxadilan and Phlebotomus papatasi sand fly salivary gland lysates on human primary in vitro immune responses. Parasite Immunol [Internet]. 2003;25:127-34. Available from: http://www.ncbi.nlm.nih.gov/pubmed/12911520.

115. Brodie TM, Smith MC, Morris RV, Titus RG. Immunomodulatory effects of the Lutzomyia longipalpis salivary gland protein maxadilan on mouse macrophages. Infect Immun [Internet]. 2007;75:2359-65. Available from: http://www.ncbi.nlm.nih.gov/pubmed/17339357.

116. Wheat WH, Pauken KE, Morris RV, Titus RG. Lutzomyia longipalpis salivary peptide maxadilan alters murine dendritic cell expression of CD80/86, CCR7, and cytokine secretion and reprograms dendritic cell-mediated cytokine release from cultures containing allogeneic T cells. J Immunol [Internet]. 2008; 180:8286-98. Available from: http://www.ncbi.nlm.nih.gov/pubmed/18523295.

117. Waitumbi J, Warburg A. Phlebotomus papatasi saliva inhibits protein phosphatase activity and nitric oxide production by murine macrophages. Infect Immun [Internet]. 1998;66:1534-7. Available from: http://www.ncbi. nlm.nih.gov/pubmed/9529078.
118. Titus RG, Bishop JV, Mejia JS. The immunomodulatory factors of arthropod saliva and the potential for these factors to serve as vaccine targets to prevent pathogen transmission. Parasite Immunol [Internet]. 2006;131. Available from: http://www.ncbi.nlm.nih.gov/pubmed/16542315.

119. Sacks D, Anderson C. Re-examination of the immunosuppressive mechanisms mediating non-cure of Leishmania infection in mice. Immunol Rev [Internet]. 2004;201:225-38. Available from: http://www.ncbi.nlm.nih. gov/pubmed/15361244.

120. De Freitas LA, Mbow LM, Estay M, Bleyenberg JA, Titus RG. Indomethacin treatment slows disease progression and enhances a Th1 response in susceptible BALB/c mice infected with Leishmania major. Parasite Immunol [Internet]. 1999;21:273-7. Available from: http://www.ncbi.nlm.nih.gov/ pubmed/10320625.

121. Carvalhal DG, Barbosa Jr A, D'El Rei Hermida M, Clarencio J, Pinheiro Jr NF, Veras PS, et al. The modelling of mononuclear phagocyte-connective tissue adhesion in vitro: application to disclose a specific inhibitory effect of Leishmania infection. Exp Parasitol [Internet]. 2004;107:189-99. Available from: http://www.ncbi.nlm.nih.gov/pubmed/15363945.

122. Steigerwald M, Moll H. Leishmania major modulates chemokine and chemokine receptor expression by dendritic cells and affects their migratory capacity. Infect Immun [Internet]. 2005;73:2564-7. Available from: http:// www.ncbi.nlm.nih.gov/pubmed/15784607

123. Pinheiro Jr NF, Hermida MD, Macedo MP, Mengel J, Bafica A, Dos Santos WL. Leishmania infection impairs beta 1-integrin function and chemokine receptor expression in mononuclear phagocytes. Infect Immun [Internet]. 2006;74:3912_ 21. Available from: http://www.ncbi.nlm.nih.gov/pubmed/16790764.

124. Figueira CP, Carvalhal DG, Almeida RA, Hermida M, Touchard D, Robert P, et al. Leishmania infection modulates beta-1 integrin activation and alters the kinetics of monocyte spreading over fibronectin. Sci Rep [Internet]. 2015;5: 12862. Available from: http://www.ncbi.nlm.nih.gov/pubmed/26249106.

125. Hynes RO. The extracellular matrix: not just pretty fibrils. Sci United States. 2009;326:1216-9.

126. Larsen M, Artym W, Green JA, Yamada KM. The matrix reorganized: extracellular matrix remodeling and integrin signaling. Curr. Opin. Cell Biol. United States. 2006;18:463-71.

\section{Submit your next manuscript to BioMed Central and we will help you at every step:}

- We accept pre-submission inquiries

- Our selector tool helps you to find the most relevant journal

- We provide round the clock customer support

- Convenient online submission

- Thorough peer review

- Inclusion in PubMed and all major indexing services

- Maximum visibility for your research

Submit your manuscript at www.biomedcentral.com/submit
Biomed Central 